\title{
CONGRESS: OPENING ADDRESS
}

\section{Dr E H Venter ${ }^{\star}$}

Madam chair, honoured guests, ladies and gentlemen - thank you for your invitation to deliver the opening address on this auspicious occasion. The theme of your symposium, namely "Physiotherapy in Perspective", is a broad one, allowing for the exploration of the role of physiotherapists at various levels of health care and in specific conditions or illnesses, but also for exploring the underlying philosophies of other professions.

Die Suid-Afrikaanse Fisioterapie Vereniging het sedert sy instelling in 1925 reeds diep spore getrap wat die ontwikkeling van die beroep in Suid-Afrika betref. Sy lidmaatskap het vanjaar tot 2,000 gestyg, wat beteken dat ongeveer $75 \%$ van alle geregistreerde fisioterapeute lede van die Vereniging is. Die Vereniging het ook in 1990 'n besondere mylpaal bereik met die daarstelling van 'n Afdeling vir Voortgesette Fisioterapie Opleiding met die doel om na-registrasie kursusse op nasionale vlak te bevorder en aan te bied. Ek verneem ook dat daar groter planne vir hierdie jaar is en wens u graag voorspoed toe met al u ondernemings.

It has been said that health care systems and professions, like industry or similar undertakings, cannot maintain status quo. To do that would in fact be to regress. There are many reasons why change in our health care system in South Africa is imperative. Some of the reasons for this are

- a population growth projected to reach 38 million by the year two thousand;

- the ageing of the South African population, bringing with it the more complex health and social problems of the elderly;

- the infant mortality rate, regarded as a good indicator, not only of the quality of health care but also of the socio-economic status of a country, remains unacceptably high and needs to be addressed on all fronts;

- the high per capita expenditure on health care which is $6,4 \%$ of the Gross National Product and already exceeding by far the World Health Organisation's target of $5 \%$ by the year 2000 . Political and social change in South Africa inevitably demands that priorities be set in relation to government expenditure. High on the list are education and housing. If the health care system is to compete successfully for funds, results will have to be produced to demonstrate cost-effectiveness and success in dealing with major health issues;

- AIDS, the most devastating disease known to mankind, will require far greater ingenuity than health professionals have thus far been able to muster, and lastly

- urbanisation is a phenomenon with which all of us will have to come to terms in spite of the almost insurmountable difficulties which it presents in terms of health and social services.

The question inevitably arises whether anything is being done to restructure the health care system in order to adapt to the changing needs in South Africa. The answer is yes, much has been done, although some important aspects are dependent upon the negotiations for a new constitution.

Government has accepted, in principle, the restructuring of a comprehensive, rationalised health care system based upon primary health care,

- a system which is accessible, equitable, affordable, effective and acceptable and

- which is rendered by both state and private sector in a partnership relationship.

It is frequently easier to determine policy than to direct the process of change by orchestrating the implementation of policy. The process of change in the health care system is directly related to the willingness of people, particularly the health care professionals, to examine and analyse their own roles and to try to understand the roles of others. Introspection and evaluation against the principles mentioned earlier may lead all of us to redetermine priorities within our professions.

It is natural for a profession to strive for excellence. The need to do so is not contested. It is my contention, however, that we need to be able to say, unequivocally, that our patient's needs and the needs of the total population are being met within the financial constraints in this time of change. We need to have clarity regarding our own role and those of others, including lay health workers, in all areas of a comprehensive system.

The planning of health manpower, particularly relating to relevancy for the future, is no easy task. The Department of National Health and Population Development is in the process of determining national norms for the various professions. Data evaluated thus far shows a concentration of health professionals in high density areas. This also is the case with physiotherapists. I am also aware of the fact that approximately $80 \%$ of the 2,784 registered physiotherapists in South Africa are in private practice and that, as a profession, you are concerned about the salaries and conditions of service of your mem. bers in State employ. These latter matters have been brought to the attention of the Minister concerned since they fall outside the scope of my portfolios. I am hopeful however, that your valuable contribution to the formulation of policy concerning rehabilitation services will be made available at national level in the near future.

I firmly believe, however, that as a health care profession, you should ask yourselves what the unique function of physiotherapy is in an Africa context. It is of concern to me that your current training programmes may be equipping physiotherapists for private practice, this in the light of possibly total ignorance on the part of $90 \%$ of the population of the existence of this important aspect of health care. An evaluation of the relevancy of selection procedures, curriculum content and where training takes place as well as the scope of practice of physiotherapists seems to me to be a good starting point to an evaluation process. The profession alone can answer questions of relevancy and manpower development and distribution. Change can only be initiated from within the profession itself.

The challenge facing all of us is to initiate and participate in a process of sustainable change so that the health care system in our new South Africa demonstrates the values to which we as caring professions subscribe.

May I therefore wish you frank and positive discussions during this symposium, discussions which benefit the group as a whole but also the individual practitioner who is seeking personal and professional growth.

Madam Chair, it now gives me great pleasure to declare this national symposium, "Physiotherapy in Perspective", open. 